\title{
PUBLIC DEBT AND ITS PLACE IN THE MACROECONOMIC POLICY OF THE REPUBLIC OF UZBEKISTAN
}

\author{
${ }^{1}$ Kurpayanidi Konstantin Ivanovich \\ ${ }^{1}$ Doctor of philosophy in Economics, \\ associate Professor, \\ Ferghana Polytechnic Institute, \\ Corresponding member of the International \\ Academy of theoretical and applied Sciences \\ (USA), \\ Professor of the Russian Academy of \\ natural Science ,ORCID id: 0000-0001-8354-1512
}

\author{
${ }^{2}$ Mukhsinova Shakhrizoda Odiljon qizi \\ ${ }^{2}$ First-year student, Faculty of production \\ management \\ Ferghana Polytechnic Institute \\ Uzbekistan, Ferghana,
}

Article DOI: $\underline{\text { https://doi.org/10.36713/epra4452 }}$

\begin{abstract}
In this article, the authors consider modern approaches and methodology for defining the concept of public debt in the national economy. The author's interpretation of the economic category of public debt is given on the basis of the system analysis of literary sources. The activities carried out by the government of the Republic of Uzbekistan in the external borrowing market are studied separately, and projects implemented at the expense of the state debt are considered. The necessity of reasonable use of borrowings in long - term and medium-term projects is proved. Based on the analysis of the Japanese Plan to revive economic growth, or the "Three arrows plan" of $S$. Abe, the directions for regulating public debt for the conditions of the Republic of Uzbekistan are proposed.
\end{abstract}

KEYWORDS: Public debt, borrowing, debt composition, state regulation, S. Abe's "Three arrows plan", economy of Uzbekistan.

\subsection{INTRODUCTION}

In the context of accelerated integration of Uzbekistan into the global financial system in the framework of implementation of the Strategy five priority directions of development of the Republic of Uzbekistan for 2017-2019 maintaining safe levels and efficient management of public debt is one of the basic conditions for sustainable economic growth in the medium and long term. It should be noted that the bulk of the borrowing, brought on behalf of the Republic of Uzbekistan or under its guarantee, aimed at projects to improve the living conditions of the population, as well as projects of development of infrastructure and basic industries. Given the continuing high demand for investment in the economy, these projects are aimed at creating the necessary infrastructure for further economic development, expanding and modernizing production capacities, increasing their competitiveness and developing entrepreneurship among the population. At the same time, taking into account that maintaining public debt at a safe level is one of the main factors for ensuring macroeconomic stability in the future, special importance is attached to improving the efficiency of public debt management based on international standards.

\subsection{LITERATURE REVIEW}

Public debt is a well-studied area for the country's economy, but the development of new problems that contribute to the increase in public debt requires new methods of solving it. Thus, it is worth studying existing research, which creates certain restrictions for studying it. Many experts have their own point of view when considering and analyzing the national debt in their research papers.

These are the works of such scientists as Cúrdia, V., \& Woodford, M.[8], Dolan, E. J., Campbell, K., \& Campbell, R. [9], Gomez-Gonzalez, P. [10], Agarkova, L. V., Bagova, D. K., \& Keshtova, D. R.[1], Pavlovskaya, E. A. [3],Popova, E. A. [4], Samsonov, N. F., Barannikov, N. P., \& Strokova, I. I.[5], Smolenskaya N. I., Smolenskaya N.E.[6], Tursunova, M. M. [7] and others. 


\subsection{RESEARCH METHODOLOGY}

The methodological basis of the research is the research approach, analog approach, dialectical approach, situational approach, methods of logical and comparative analysis, observation methods and static methods.

\subsection{ANALYSIS AND RESULTS}

In the modern economy, the financial position of the government and its prospects are determined by the state budget, the amount of its deficit, and the amount of public debt - an aggregate characteristic of this deficit. For the concept of what constitutes a public debt, it is necessary to refer to the legislation of the Republic of Uzbekistan. In article 3 (Basic concepts applied in this Code) The Budget Code of the Republic of Uzbekistan defines public debt as the obligations of the Republic of Uzbekistan arising as a result of internal and external borrowings [2].

State internal borrowing is the attraction of funds from residents of the Republic of Uzbekistan, for which there are obligations of the Republic of Uzbekistan as a borrower or guarantor of repayment of loans by resident borrowers.

State external borrowing is the attraction of funds from foreign sources (foreign States, international organizations, international financial and economic institutions, foreign government financial organizations and other non-residents of the Republic of Uzbekistan), under which the obligations of the Republic of Uzbekistan arise as a borrower or guarantor of repayment of loans by resident borrowers [7].

Now, to analyze accurately public debt and its impact on the government's economy, we need to formulate the essence of public debt. To do this, it is necessary to give several points of view of scientistseconomists regarding the economic essence of public debt.

So, according to the definition of C. R. McConnell and S. L. Brue, "the national debt is the total accumulated amount of all positive balances of the Federal government's budgets, minus all deficits that occurred in the country"[21].

According to the authors of the book "Applied Economics" Junior Achievement ${ }^{\circledR}$ : "public debt - the amount of debt owed by the state to individuals and legal entities, foreign States, international organizations and other entities, including accrued interest" [6].

Thus, E. A. Popova believes that "the definition of public debt, which is a legal form of public financial obligations of the state to legal entities and individuals, public legal entities"[4].

According to E. A. Pavlovskaya, "the system of public debt management should be understood as a set of measures directed by the state to determine the necessity, conditions for attracting, servicing and repayment of public loans in order to ensure public interests, without violating the economic security of the state" [3].
According to Dolan, E. J., Campbell, K., \& Campbell, R. "public debt is the accumulated amount of budget deficits of previous years" [9].

According to the definition Of N. F. Samsonov, N. L. Barannikov, and N. I. Strokova, "public debt is the sum of arrears on issued and outstanding debt obligations of the state, including interest accrued on them" [5].

Another group of authors, Agarkova, L. V., Bagova, D. K., \& Keshtova, D. R., believes that "the state internal debt is the debt obligations of a public legal entity" [1].

In general, we can agree with these concepts of public debt, all of them to some extent give an idea of the public debt. At the same time, they are in principle incomplete and do not express the deeper meaning of this category.

Generalizing and taking into account the literature supply, the most complete, in our opinion, is the following definition:

"Public debt is the total accumulated amount of debt owed on issued and outstanding debt obligations of the state to individuals and legal entities, foreign States, international organizations and other entities, including accrued interest on a certain date."

The external debt of the Republic of Uzbekistan is recorded as the balance of debt on foreign borrowings of residents of the Republic of Uzbekistan, as well as accrued but unpaid interest on foreign borrowings. The external debt of the private sector consists of external borrowings received without a guarantee from the government of the Republic of Uzbekistan, including debt on loans submitted by foreign parent companies. Information on the external debt of the private sector is provided by commercial banks. Data on the external debt of the private sector is formed by sectors of the economy (oil and gas, energy, banking, telecommunications, textiles, and other sectors). In addition, banks provide data on forecasts of repayment of principal and interest. [10-23].

The total external debt of the Republic of Uzbekistan as of January 1, 2020 amounted to 24.4 billion dollars, an increase of $40.9 \%$ or 7.1 billion dollars in relation to the beginning of 2019, according to the report of the Central Bank. [12].

The increase in debt during 2019 was mainly accounted for by the public sector ( $\$ 5.7$ billion), of which $\$ 1$ billion was international bonds. Private sector debt increased by $\$ 1.4$ billion because of increased borrowing by banks and other sectors of the economy.

It is noted that in 2019, the private sector attracted loans totaling $\$ 2.8$ billion. Banks ( $\$ 2.1$ billion), oil and gas and energy companies (\$208.2 million), textile companies ( $\$ 131$ million), and enterprises in other sectors of the economy ( $\$ 391.2$ million) mainly carried out borrowing. 


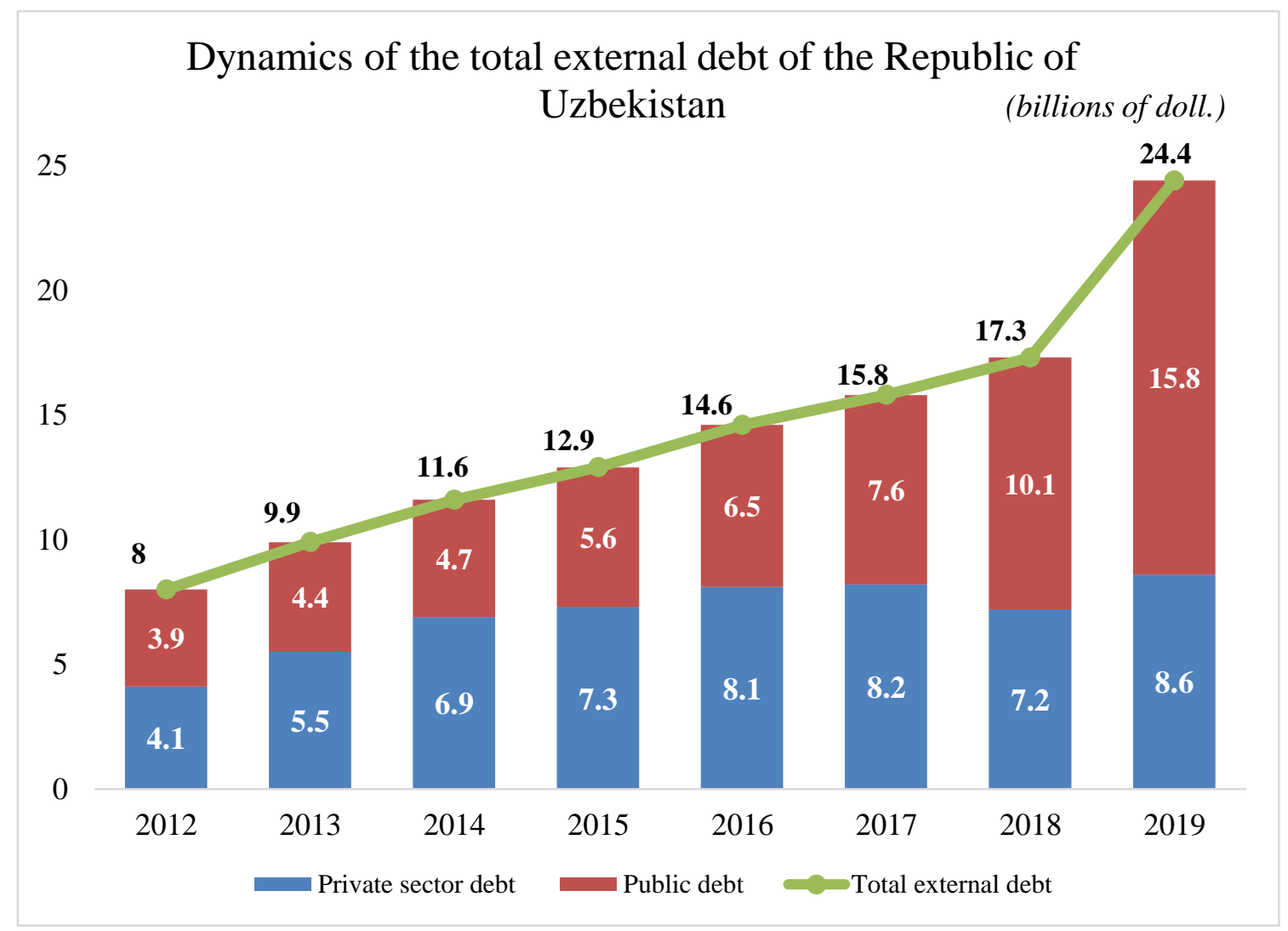

Pic. 2.1.1 Dynamics of the total external debt of the Republic of Uzbekistan

At the expense of the state debt, 39 projects are currently being implemented to provide drinking water and improve water supply, 30 projects in the field of education and health, seven projects in the field of housing construction, and others. Here are a few major such projects [13]:

Table 1 Projects implemented at the expense of government debt

\begin{tabular}{|c|c|c|c|}
\hline Project & Deadlines & $\begin{array}{l}\text { Development } \\
\text { (in millions \$) }\end{array}$ & What will give \\
\hline $\begin{array}{l}\text { The production of synthetic } \\
\text { liquid fuel based on cleaned } \\
\text { methane of Shurtan } \\
\text { chemical complex }\end{array}$ & $2016-2020$ & 1063,9 & $\begin{array}{l}1.52 \text { million tons of fuel will be } \\
\text { produced and more than } 1,300 \\
\text { jobs will be created. }\end{array}$ \\
\hline $\begin{array}{c}\text { Construction and } \\
\text { modernization of thermal } \\
\text { power plants Takhiatash, } \\
\text { Navoi and Turakurgan }\end{array}$ & $2015-2020$ & 406,8 & $\begin{array}{l}\text { Electricity supply in Bukhara, } \\
\text { Samarkand and the Fergana valley } \\
\text { will be stabilized. }\end{array}$ \\
\hline $\begin{array}{c}\text { Reconstruction and } \\
\text { construction of water } \\
\text { supply and Sewerage } \\
\text { systems in cities and } \\
\text { districts of the Tashkent } \\
\text { region }\end{array}$ & $2017-2021$ & 5,7 & $\begin{array}{l}\text { Drinking water supply to } 265 \\
\text { thousand residents of } 58 \text { rural } \\
\text { localities will be improved, and the } \\
\text { coverage of drinking water will be } \\
\text { increased from } 60 \text { to } 92 \% \text {. }\end{array}$ \\
\hline $\begin{array}{l}\text { Development of the } \\
\text { sewerage system of the city } \\
\text { of Jizzakh }\end{array}$ & $2016-2020$ & 14,4 & $\begin{array}{l}77.2 \text { thousand residents of the city } \\
\text { will be able to provide centralized } \\
\text { Sewerage services, and the } \\
\text { sanitary and epidemiological state } \\
\text { of the city will be improved. }\end{array}$ \\
\hline $\begin{array}{l}\text { Strengthening the material } \\
\text { and technical base of higher } \\
\text { educational institutions }\end{array}$ & $2017-2022$ & 3,0 & $\begin{array}{l}\text { It provides for improving the } \\
\text { quality of education and providing } \\
\text { laboratory equipment for higher }\end{array}$ \\
\hline
\end{tabular}




\begin{tabular}{|c|c|c|c|}
\hline & & & educational institutions. \\
\hline $\begin{array}{c}\text { Reconstruction of 87 km.a- } \\
\begin{array}{c}380 \text { Guzar-Bukhara - } \\
\text { Nukus - Beineu highway } \\
\text { on the section 228-315 km. }\end{array}\end{array}$ & $2016-2020$ & 0,2 & 87 km of roads will be built. \\
\hline $\begin{array}{c}\text { The project of housing } \\
\text { construction in rural areas }\end{array}$ & $2017-2020$ & 79,2 & 2,606 new homes will be built. \\
\hline $\begin{array}{c}\text { Modernization of solid } \\
\text { waste management in the } \\
\text { city of Samarkand }\end{array}$ & $2017-2021$ & 1,4 & $\begin{array}{c}\text { It will be possible to process } 360 \\
\text { thousand tons of solid household } \\
\text { waste per year. }\end{array}$ \\
\hline
\end{tabular}

Conclusion: The largest project that was implemented at the expense of the state debt is considered to be "production of synthetic liquid fuel based on purified methane of the Shurtan chemical complex", which will be completed in 2020 and will give 1.52 million tons of fuel and more than 1,300 jobs, which will increase the country's economy significantly. In General, every project that is implemented at the expense of public debt is aimed at improving the lives of the population and increasing the country's income after their terms are over.

However, in order to further improve the system of public debt management of the Republic of Uzbekistan based on international standards and maintain at a level safe for macroeconomic stability and the development of mechanisms to ensure the effective use of advantage, the following measures:

- Jointly, with the World Bank and the International monetary Fund has developed a draft Medium-term strategy of public debt management;

- Based on the instructions of the International monetary Fund on the implementation of fiscal rules, calculations were made for the maximum allowable level of public debt to GDP, as well as the safe level of public debt for macroeconomic stability based on multiscenario forecasts;

- Measures have been developed to maintain public debt at a level that is safe for macroeconomic stability in the short and long term;

- The process of automation of monitoring, servicing, accounting and reporting of the state debt of the Republic of Uzbekistan continues (the software package "debt management and financial analysis System" - "DMFAS-6" is installed);

- Measures are being implemented to ensure the openness and availability of public debt data;

- In order to prevent the negative impact of public debt risks on the stability of the state budget, additional measures are being developed to improve the system of providing state guarantees based on international experience.
- As for other measures in the field of macroeconomic policy and structural reforms, the draft Decree provides for:

- revision of methods and principles of directed lending within the framework of state targeted programs with the establishment of interest rates from January 1, 2020 at a level not lower than the Central Bank refinancing rate, and from January 1, 2021 free market rates using, if necessary, compensation mechanisms for part of interest expenses;

- measures in the field of fiscal policy aimed at developing "budget rules" and introducing the practice of approving the maximum annual parameter for changes in internal and external public debt from 2020;

- ensuring strict execution of the State budget within the established parameters, as well as consistency of fiscal and monetary policy;

- establishing an order in accordance with which decisions on further economic reform will be based on principles and objectives that ultimately meet the goals of high quality and sustainable economic growth and ensure price stability.

This, in turn, includes the creation of modern industrial, transport and social infrastructure, the completion of the liberalization of regulated prices, the development of a competitive environment, improving the effectiveness of state-owned enterprises ' reforms through the widespread introduction of market mechanisms in their activities, increasing labor productivity and energy efficiency.

Application of foreign experience in reducing the volume of public debt on the example of Japan.

In 2013, the country adopted a Plan to revive economic growth, or the "three arrows Plan" of S. Abe. In the "second arrow" section of events, it was supposed to switch to a strategy of flexible budget policy, which allowed the Japanese government to resort to significant investments, despite the excess of the expenditure part of the state budget over the revenue. 
Table 2. S. Abe's "Three arrows plan" (2013-2017) ${ }^{1}$

\begin{tabular}{|c|c|c|c|}
\hline $\begin{array}{c}\text { "Three } \\
\text { arrows } \\
\text { plan" by S. } \\
\text { Abe " }\end{array}$ & $\begin{array}{l}\text { Plan to revive } \\
\text { economic } \\
\text { growth }\end{array}$ & \multicolumn{2}{|c|}{$\begin{array}{l}\text { GDP growth } \\
\text { rate }\end{array}$} \\
\hline \multirow{2}{*}{$\begin{array}{l}\text { Measures to } \\
\text { promote the } \\
\text { pace of } \\
\text { economic } \\
\text { development }\end{array}$} & The first arrow & (plan) & (fact) \\
\hline & $\begin{array}{l}\text { - large-scale } \\
\text { monetary } \\
\text { stimulus } \\
\text { The second } \\
\text { arrow - flexible } \\
\text { fiscal policy } \\
\text { The third arrow } \\
\text { is the structural } \\
\text { adjustment of } \\
\text { the economy } \\
\text { (growth } \\
\text { strategy). }\end{array}$ & 3,2 & 0,6 \\
\hline
\end{tabular}

The main goals of the Plan were declared: overcoming long-term deflation; doubling the Bank of Japan's money supply in order to reduce interest rates on loans; creating new demand for goods and services; flexible attitude to budget spending - despite the significant deficit of the state budget, to invest $\$ 200$ billion in the real economy. In addition, it was planned to increase labor productivity, assist the development of the private sector, small and medium-sized businesses, reduce income taxes, review labor and immigration laws, and other measures.

Since the beginning of the global financial and economic crisis in 2008, Japan and other countries have used methods of financial repression to solve the problem of public debt: maintaining negative real returns on deposits and government bonds [11], placing public debt in government-controlled financial institutions, setting special reserve requirements, as well as restrictions on the movement of investments in the national financial sector.

Japan actively uses the method of non-market placement of government debt in the accounts of dependent financial institutions, usually banks with close ties to the Ministry of Finance and the Central Bank of Japan. Tight control over the financial sector leads to distortion of market mechanisms for determining the return on assets. Financial repression implies some isolation of the country's financial sector from the international financial market and its protection from turbulence and global cataclysms.

Despite the increase in public debt, Japan ranks 3rd in GDP in the world. At the same time, the government's measures to reduce the national debt can only work at low interest rates, but it is worth taking examples for paying off the national debt of the Republic of Uzbekistan.

In the «plan of three arrows» for Uzbekistan, it is worth applying 2 and 3 arrows, because over the course

\footnotetext{
${ }^{1}$ Кейдзай симбун, 12.07.2014, International Monetary Fund, World Economic Outlook Database, April 2019.
}

of 4 years, the increase in the money supply by issuing new monetary units in Uzbekistan occurred. The second arrow directs the government to resort from investments, i.e. to reduce their quantity. Before investing, a country should think about everything from the outside and choose the most suitable one that brings the highest income among the others. The third arrow says that it is necessary to rebuild the country's economy, i.e. choose the sphere that is the universal and suitable for entrepreneurs in the country.

In addition, the current situation with the pandemic in Uzbekistan may affect the amount of public debt and the government's measures for such situations will show how well the country was prepared to deal with emergencies. [16,17,18,19,20].

\subsection{CONCLUSION}

Thus, the study showed that public debt plays an important role in the country's economy. The reduction of public debt in the Republic of Uzbekistan in the conditions of digitalization with a specific drawn up plan gives certain results and at the same time, mechanisms are being developed to ensure the effective use of borrowed funds. The use of foreign experience is also important for the government, since it considers the experience that has already been considered by the leading country in the world and has its results by applying it.

\section{REFERENCES}

1. Agarkova, L. V., Bagova, D. K., \& Keshtova, D. R. (2018). Gosudarstvennyj dolg Rossijskoj Federacii. In Nauchnye issledovaniya $i$ razrabotki 2018 (pp. 125-130).

2. Byudzhetnyj kodeks Respubliki Uzbekistan 26.12.2013 Razdel I. Obshchie polozheniya Glava 1. Osnovnye polozheniya Stat'ya 3

3. Pavlovskaya, E. A. (2013, October). Sistema upravleniya gosudarstvennym dolgom. In Aktual'nye voprosy ekonomiki $i$ upravleniya: materialy II Mezhdunar. nauch. konf.(Moskva.)

4. Popova, E. A. Pravovoe regulirovanie vneshnego $i$ vnutrennego gosudarstvennogo dolga Rossijskoj Federacii // Molodoj uchenyj. - 2019. — № 47 (285). - S. 359-362.

5. Samsonov, N. F., Barannikova, N. P., \& Strokova, I. I. (2019). Finansy na makrourovne: uchebnoe posobie. M.: Vysshaya shkola.

6. Smolenskaya N.I., Smolenskaya N.E. Junior Achievement ${ }^{\circledR}$ «Prikladnaya ekonomika» - Moskva «Prosveshchenie», 1998 - s.178

7. Tursunova, M. M. (2016). Sushchnost' $i$ znachenie gosudarstvennogo dolga $v$ ekonomike. Molodoj uchenyj, (10), 902-904.

8. Cúrdia, V., \& Woodford, M. (2016). Credit frictions and optimal monetary policy. Journal of Monetary Economics, 84, 30-65.

9. Dolan, E. J., Campbell, K., \& Campbell, R. (2007). Money, Banking and monetary and credit policy.

10. Gomez-Gonzalez, P. (2019). Public debt structure and liquidity provision. Journal of International Economics, 117, 51-60. 
11. http://databank.worldbank.org/data/reports/aspx?sou rce $=2 \&$ series $=$ FR.INR RINERandcountry (accessed 25.10.2019)

12. https://kun.uz/ru/news/2020/03/27/vneshniy-dolguzbekistana-po-itogam-2019-goda-prevysil-24-mlrddollarov

13. https://www.spot.uz/ru/2020/01/08/debt/

14. IMF (International Monetary Fund). (2015). World Economic Outlook Database, April 2015.

15. International Monetary Fund, World Economic Outlook Database, April 2019.

16. Kurpayanidi, K., Abdullaev, A., Khudaykulov, A. (2020) Challenges of coping with the economic consequences of the global pandemic COVID-19. ISJ Theoretical \& Applied Science, 05 (85).

17. Kurpayanidi, K., Abdullaev, A., Ashurov M., T.Tukhtasinova, M. (2020) The issue of a competitive national innovative system formation in Uzbekistan. E3S Web Conf., 159, $04024 . \quad$ DOI: https://doi.org/10.1051/e3sconf/202015904024

18. Kurpayanidi, K. I. (2019). Theoretical basis of management of innovative activity of industrial corporation. ISJ Theoretical \& Applied Science, 01 (69), 7-14. Soi: http://s-o-i.org/1.1/TAS-01-69-3 Doi: https://dx.doi.org/10.15863/TAS.2019.01.69.

19. Kurpayanidi, K. I. (2020). Actual problems of implementation of investment industrial entrepreneurial potential. ISJ Theoretical \& Applied Science, 01 (81), 301-307. Soi: http://s-oi.org/1.1/TAS-01-81-54 Doi: https://dx.doi.org/10.15863/TAS.2020.01.81.54

20. Kurpayanidi, K. I. (2020). On the problem of macroeconomic analysis and forecasting of the economy. ISJ Theoretical \& Applied Science, 03 (83), 1-6. Soi: http://s-o-i.org/1.1/TAS-03-83-1 Doi: https://dx.doi.org/10.15863/TAS.2020.03.83.1

21. McConnell, C. R., Brue, S. L., \& Flynn, S. M. (2009). Economics: Principles, problems, and policies. Boston McGraw-Hill/Irwin.

22. Nurgazina, A. M., \& Singh, A. K. (2019). Monetary and Credit Instruments for the Improvement of Financial Market's Instability. Central Asian Journal of Social Sciences and Humanities, 1(1), 3-5.

23. Zwass, A. (2017). Money, Banking \& Credit in the soviet union \& eastern europe. Routledge. 